\title{
Genetic conservation of potentially immunogenic proteins among Brazilian isolates of Babesia bovis
}

\author{
Carlos A.N. Ramos a,b,*, Flábio R. Araújo ${ }^{b}$, Leucio C. Alves ${ }^{a}$, Ingrid Ieda Fernando de \\ Souza $^{\mathrm{b}, \mathrm{c}}$, Daniel S. Guedes Jr ${ }^{\mathrm{d}}$, Cleber Oliveira Soares ${ }^{\mathrm{b}}$ \\ a Laboratório de Doenças Parasitárias dos Animais Domésticos, Departamento de Medicina Veterinária-UFRPE, Recife, PE 52171-900, Brazil \\ b Embrapa Gado de Corte, Campo Grande, MS 79002-970, Brazil \\ c UFMS, Campo Grande, MS 79070-900, Brazil \\ d FIOCRUZ, Bio-Manguinhos, Rio de Janeiro, RJ 21040-360, Brazil
}

\section{A R T I C L E I N F O}

\section{Article history:}

Received 28 October 2011

Received in revised form 9 January 2012

Accepted 11 January 2012

\section{Keywords:}

Genetic conservation

Babesia bovis

Vaccine

Brazil

\begin{abstract}
A B S T R A C T
Bovine babesiosis caused by Babesia bovis remains an important constraint for the development of cattle industries worldwide. Effective control can be achieved by vaccination with live attenuated phenotypes of the parasite. However, these vaccines have a number of drawbacks, which justifies the search for better, safer vaccines. In recent years, a number of parasite proteins with immunogenic potential have been discovered. However, there is little information on the genetic conservation of these proteins among different parasite isolates, which hinders their assessment as immunogens. The aim of the present study was to evaluate the conservation of the genes ama-1, acs-1, rap-1, trap, $p 0$ and msa2c among five Brazilian isolates of $B$. bovis. Through polymerase chain reaction, genetic sequencing and bioinformatics analysis of the genes, a high degree of conservation (98-100\%) was found among Brazilian isolates of $B$. bovis and the T2Bo isolate. Thus, these genes are worth considering as viable candidates to be included in a recombinant cocktail vaccine for cattle babesiosis caused by $B$. bovis.
\end{abstract}

(C) 2012 Elsevier B.V. All rights reserved.

\section{Introduction}

Bovine babesiosis is a tick-borne disease that imposes important constraints on livestock health and economic development in tropical and subtropical regions throughout the world (McCosker, 1981). In Brazil, economic losses due to tick fever are on the order of 500 million dollars annually (Grisi et al., 2002) and most losses are likely due to infection by Babesia bovis, as this species is the aetiological agent of most outbreaks of babesiosis (Rodrigues et al., 2005; Almeida et al., 2006; Antoniassi et al., 2009; Câmara et al., 2009).

\footnotetext{
* Corresponding author at: Embrapa Gado de Corte, BR 262, Km 04, CP 154, Campo Grande, MS 79002-970, Brazil. Tel.: +55 6733682085.

E-mail address: carlosanramos@yahoo.com.br (C.A.N. Ramos).
}

B. bovis infection is characterised by fever, anaemia, jaundice, sequestration of infected erythrocytes in the host microvasculature, hypotensive shock and often the death of infected animals (Wright and Goodger, 1988).

Vaccination against $B$. bovis is a widespread method used to diminish the impact of clinical disease (Nari et al., 1979; Kessler et al., 1987; Callow et al., 1997; De Vos and Bock, 2000; Ojeda et al., 2010). However, the available vaccines are based on bovine blood infected with live attenuated organisms (Nari et al., 1979; Kessler et al., 1987). Despite inducing a strong protective immune response in vaccinated animals, these vaccines have limitations, such as the transmission of other blood-borne pathogens, failure due to vaccine breakdown (De Vos and Bock, 2000), the possibility of reversion to virulence and a short shelf life in the case of chilled vaccines. Moreover, there are important ethical implications related to the production of a live 
vaccine due to the need for artificially infected cattle in order to obtain large volumes of infected blood (Kessler et al., 1987; Callow et al., 1997).

The search for better, safer vaccines has been based on the investigation into novel immunogenic proteins that can provide a good level of protection and better safety in comparison to current vaccines. Recombinant DNA techniques have enabled the production of many such proteins with immunogenic potential (Gaffar et al., 2004a,b; Norimine et al., 2006).

Several genes that encode $B$. bovis proteins with immunogenic potential are currently known, especially after the sequencing of the genome of this protozoan (isolate T2Bo, Texas, USA) (Brayton et al., 2007). Some of these antigens were pointed as potentially immunogenic proteins, based on fractioning of merozoite proteins or culture supernatants and testing of individual fractions tested for induction of protective immunity in cattle or animal models; antibody or T-cell-proteomic approaches; genomic approach or the combination proteomic-genomic approach, as reviewed by Brown et al. (2006).

However, information on the conservation of genes that encode remains scarce (Perez et al., 2010). Such knowledge is important, as various proteins may elicit protective responses only against homologous isolates and outbreaks of the disease may involve the challenge of heterologous isolates.

The aim of the present study was to evaluate the conservation of genes ama-1, acs-1, rap-1, trap, $p 0$ and msa2c, that encode potentially immunogenic proteins among different Brazilian strains of $B$. bovis.

\section{Material and methods}

\subsection{Isolates}

Five Brazilian isolates of $B$. bovis from the states of Bahia, São Paulo, Rio Grande do Sul, Mato Grosso do Sul and Rondônia were used, representing all physiographic regions of Brazil: Northeast (NE), Southeast (SE), South (S), Midwest (MW) and North (N), respectively (Kessler et al., 1998).

\subsection{DNA extraction}

Genomic DNA from Brazilian isolates of $B$. bovis was obtained from $350 \mu \mathrm{L}$ of infected bovine blood using the Easy DNA kit (Invitrogen Carlsbad, CA, USA), following the manufacturer's instructions. The integrity and concentration of DNA samples were assessed by agarose gel electrophoresis $0.8 \%$ and NanoDrop ND1000 (Thermo Scientific, Waltham, MA, USA).

\subsection{Gene amplification and cloning}

For the sequence analysis, whole open reading frames of the genes ama-1, acs-1, rap-1, trap, p0 and msa2c from the five Brazilian isolates were amplified by polymerase chain reaction (PCR) and cloned with pGEM-T Easy (Promega Co., Madison, WI, USA), following the manufacturer's instructions. Amplifications of the whole genes were performed in different steps using specific primer sets designed to amplify $~ 500 \mathrm{bp}$ fragments with overlapping ends (Supplementary File 1 ).

All amplification reactions were performed in a volume of $25 \mu \mathrm{L}$, containing $10 \mathrm{mM}$ of Tris- $\mathrm{HCl}$ ( $\mathrm{pH} 8.3$ ), $50 \mathrm{mM}$ of $\mathrm{KCl}, 1.5 \mathrm{mM}$ of $\mathrm{MgCl}_{2}, 0.2 \mathrm{mM}$ of each deoxynucleoside triphosphate, $12 \mathrm{pmol}$ of each primer, $100 \mathrm{ng}$ of genomic DNA and $1.25 \mathrm{U}$ of Taq DNA polymerase (Invitrogen, Carlsbad, CA, USA). Amplifications were performed in a Mastercycler thermocycler (Eppendorf, Hamburg, Germany) as follows: $94{ }^{\circ} \mathrm{C}$ for $1 \mathrm{~min}$ (denaturation); 30 cycles of $94{ }^{\circ} \mathrm{C}$ for $1 \mathrm{~min}$ (denaturation), $53{ }^{\circ} \mathrm{C}$ for $30 \mathrm{~s}$ (annealing) and $72^{\circ} \mathrm{C}$ for $40 \mathrm{~s}$ (extension); and a final cycle at $72{ }^{\circ} \mathrm{C}$ for $4 \mathrm{~min}$ (extension). PCR products were analysed by electrophoresis on $1 \%$ agarose gel stained with SybrGold (Invitrogen, Carlsbad, CA, USA).

\subsection{Gene sequencing and analysis}

The DNA sequences of the genes ama-1, acs-1, rap1, trap, $p 0$ and $m s a 2 c$ from the five Brazilian isolates of $B$. bovis were obtained using the BigDye Terminator kit and ABI3130 sequencing analyzer (Applied Biosystems, Foster City, CA, USA). For each gene studied at least five different amplicons, obtained from different PCR reactions, were sequenced. Sequences were assembled using the Sequencher v.4.1.4 software program (Gene Codes, Ann Arbor, MI, USA) and submitted to BLASTn search (http://www.ncbi.nlm.nih.gov) to determine the sequence identity. Multiple sequence alignment was performed with the ClustalW algorithm (www.ebi.ac.uk/Tools/clustalw2/index.html).

\section{Results and discussion}

The gene sequences of the Brazilian isolates of $B$. bovis were deposited in the Genbank under the accession numbers shown in Table 1.

The multiple alignment revealed levels of identity from $98 \%$ to $100 \%$ among the Brazilian isolates and between these isolates and the T2Bo isolate, the genome of which is available in the Genbank under the accession number NZ_AAXT00000000. The most conserved genes were ama1, p0, acs-1 and msa2c, which exhibited 99-100\% identity among the Brazilian isolates and between the American (T2Bo) and Brazilian isolates. The percentages of genetic identity among the Brazilian and American isolates of $B$. bovis are displayed in Table 2 .

The alignment of the acs-1 gene with the mRNA sequence (Genbank AF331454) allowed the identification of three introns between nucleotides 113 and 149, 232 and 265 and between 393 and 427.

On the amino acid level, proteins encoded by the genes analysed exhibited identities higher than $96.8 \%$, with p0 exhibiting the highest identity (100\%) among the Brazilian and T2Bo isolates. The deduced amino acid sequence of the trap protein exhibited the lowest identity (96.8\%) among the isolates analysed.

The research and development of subunit vaccines have reached significant levels in recent years, including encouraging results, as in the case of protozoan Leishmania chagasi 
Table 1

GenBank accession numbers of Babesia bovis genes analysed in five Brazilian isolates of the protozoan.

\begin{tabular}{|c|c|c|c|c|c|c|}
\hline \multirow[t]{2}{*}{ Isolates } & \multicolumn{6}{|l|}{ Gene } \\
\hline & msa2c & $a c s-1$ & p0 & ama-1 & trap & rap-1 \\
\hline Northeast & HМ352732a & FJ588015 & FJ588005 & FJ588025 & FJ588020 & FJ588010 \\
\hline Southeast & HМ352734 & FJ588017 & FJ588007 & FJ588027 & FJ588022 & FJ588012 \\
\hline South & HM352735 & FJ588018 & FJ588008 & FJ588028 & FJ588023 & FJ588013 \\
\hline Midwest & HM352731 & FJ588014 & FJ588004 & FJ588024 & FJ588019 & FJ588009 \\
\hline North & HM352733a & FJ588016 & FJ588006 & FJ588026 & FJ588021 & FJ588011 \\
\hline
\end{tabular}

a GenBank accession numbers previously published by this research group in Ramos et al. (2011).

b GenBank accession numbers previously published by this research group in Ramos et al. (2009).

(Fernandes et al., 2008) and Theileria parva (Musoke et al., 2005). With respect to B. bovis, although significant reductions in the levels of parasitemia have been achieved in cattle vaccinated with the recombinant proteins 12D3 and 11C5 (Hope et al., 2005) and RAP-1 (Wright et al., 1992), and cocktail of MSA-1, MSA-2c and 12D3 protected cattle against mild virulent strain of $B$. bovis in Mexico (Álvarez et al., 2010), total protection against the disease has not been achieved (Florin-Christensen et al., 2007), indicating the need for the identification and evaluation of other immunogenic proteins.

The high degree of conservation in the protein sequences encoded by the genes analysed in the present study indicates that important epitopes previously mapped

\section{Table 2}

Percentages of genetic identity among Brazilian and American (T2Bo) isolates of Babesia bovis for genes msa2c, acs-1, p0, trap, ama-1 and rap-1; isolates Northeast (NE), Southeast (SE), South (S), Midwest (MW) and North $(\mathrm{N})$.

\begin{tabular}{|c|c|c|c|c|c|c|c|}
\hline & & $\mathrm{NE}$ & SE & $S$ & MW & $\mathrm{N}$ & Т2Bo \\
\hline \multirow{5}{*}{$m s a 2 c$} & $\mathrm{NE}$ & - & 99 & 99 & 99 & 99 & 99 \\
\hline & SE & - & - & 99 & 99 & 99 & 99 \\
\hline & S & - & - & - & 99 & 99 & 99 \\
\hline & MW & - & - & - & - & 100 & 100 \\
\hline & $\mathrm{N}$ & - & - & - & - & - & 100 \\
\hline \multirow{5}{*}{$\operatorname{acs} 1$} & $\mathrm{NE}$ & - & 99 & 99 & 99 & 99 & 99 \\
\hline & SE & - & - & 99 & 99 & 99 & 99 \\
\hline & S & - & - & - & 100 & 99 & 99 \\
\hline & MW & - & - & - & - & 99 & 99 \\
\hline & $\mathrm{N}$ & - & - & - & - & - & 99 \\
\hline \multirow{5}{*}{$p 0$} & $\mathrm{NE}$ & - & 100 & 100 & 99 & 100 & 99 \\
\hline & SE & - & - & 100 & 99 & 100 & 99 \\
\hline & S & - & - & - & 99 & 100 & 99 \\
\hline & MW & - & - & - & - & 99 & 99 \\
\hline & $\mathrm{N}$ & - & - & - & - & - & 99 \\
\hline \multirow{5}{*}{ trap } & $\mathrm{NE}$ & - & 99 & 99 & 99 & 99 & 98 \\
\hline & SE & - & - & 99 & 99 & 99 & 98 \\
\hline & $\mathrm{S}$ & - & - & - & 99 & 99 & 98 \\
\hline & MW & - & - & - & - & 100 & 98 \\
\hline & $\mathrm{N}$ & - & - & - & - & - & 98 \\
\hline \multirow{5}{*}{ ama-1 } & $\mathrm{NE}$ & - & 99 & 99 & 99 & 99 & 99 \\
\hline & SE & - & - & 100 & 99 & 99 & 99 \\
\hline & S & - & - & - & 99 & 99 & 99 \\
\hline & MW & - & - & - & - & 99 & 99 \\
\hline & $\mathrm{N}$ & - & - & - & - & - & 99 \\
\hline \multirow{5}{*}{ rap-1 } & $\mathrm{NE}$ & - & 99 & 99 & 99 & 99 & 99 \\
\hline & SE & - & - & 99 & 99 & 99 & 99 \\
\hline & S & - & - & - & 99 & 99 & 99 \\
\hline & MW & - & - & - & - & 99 & 99 \\
\hline & $\mathrm{N}$ & - & - & - & - & - & 99 \\
\hline
\end{tabular}

in these proteins are also found in Brazilian isolates of the protozoan B. bovis. For example, the amino terminal region (N-terminal) of RAP-1 contains epitopes recognised by TCD4+ memory cells in cattle chronically infected with B. bovis (EYLVNKVLYMATMNYKT, aa 187-203, and EAPWYKRWIKKFR, aa 295-307)(Fig. 1a) (Norimine et al., 2002) and AMA-1 contains B-cell epitopes in the N-terminal region (AFHKEPPNNRRLTKRS, aa 46-60, RGVGMNWATYDKDSG, aa 395-409, and YVEPRAKNTNKYLDV, aa 453-467), the antiserum of which is able to inhibit the invasion of erythrocytes by merozoites of $B$. bovis in vitro (Fig. 1b) (Gaffar et al., 2004a). Another B-cell epitope in the TSP1 domain of the TRAP protein between amino acids 255 and 269 (PGKRTRALLDLRMIE) (Gaffar et al., 2004b) also demonstrated conservation among the Brazilian strains of the protozoan (Fig. 1c). Another epitopes for B cells in the MSA2c protein (ELLKLLIEA) and (THDALKAVKQLIKT) were also conserved (Fig. 1d). Murine antiserum reacted with these epitopes on the surface of merozoites of $B$. bovis. Moreover, serum samples from naturally and experimentally infected cattle have recognised this epitope in ELISA (Dominguez et al., 2010). The identification of T-cell epitopes in candidate vaccine antigens conserved among different geographical parasite isolates is therefore needed to develop a multiple-antigen or peptide-based vaccine.

In addition, the acs-1 protein, which demonstrated a high degree of genetic conservation between the Brazilian and American strains, induced the proliferation of TCD4+ memory cells and the production of INF- $\gamma$ in cattle chronically infected with $B$. bovis (Norimine et al., 2006), all of which are components of the Th1 protective immune response against B. bovis (Brown et al., 2006). It has recently been shown that recombinant ribosomal protein $p 0$ from B. bovis was recognised by IgG1 and IgG2 antibodies from cattle chronically infected with $B$. bovis (Ramos et al., 2009). Moreover, acs -1 and $p 0$ have been associated with protective immune responses against Plasmodium falciparum (Rajeshwari et al., 2004; Norimine et al., 2006), which is an organism related to $B$. bovis.

The search for novel immunogens against $B$. bovis has focused on functionally important proteins for the survival of the parasite (Florin-Christensen et al., 2007). The rap1, trap and ama-1 proteins are components of the apical complex protozoan and are directly related to the process of invasion of bovine erythrocytes by merozoites (Suarez et al., 1998; Gaffar et al., 2004a,b), which is of fundamental importance to the survival and perpetuation of parasites. The msa2c protein is component of a family of polymorphic GPI-anchored glycoproteins located on the cell surface 
a

\begin{tabular}{|c|c|c|c|c|}
\hline \multicolumn{2}{|c|}{ Epitope } & 181 & ------EYLVNKVLYMATMNYKT--- & 20 \\
\hline RAP & $1 \mathrm{MW}$ & 181 & EGTTDVEYLVNKVLYMATMNY KTYLT & 206 \\
\hline Af & $1 \mathrm{~N}$ & 181 & EGTTDVEYLVNKVLYMATMNYKTYLT & 06 \\
\hline & SE & 181 & EGTTDVEYLVNKVLYMATMNYKTYLT & 06 \\
\hline & NE & 181 & EGTTDVEYLVNKVLYMATMNYKTYLT & 06 \\
\hline & $\mathbf{S}$ & 181 & EGTTDVEYLVNKVLYMATMNYKTYLT & \\
\hline
\end{tabular}

287 --------EAPWYKRWI KKER--- 310

287 LGSLTSYVEAPWYKRWI KKFRDFF 310

287 LGSLTSYVEAPWYKRWI KKFRDFF 310

287 LGSLTSYVEAPWYKRWI KKFRDFF 310

287 LGSLTSYVEAPWYKRWI KKFRDFF 310

287 LGSLTSYVEAPWYKRWIKKFRDFF 310

\section{b}

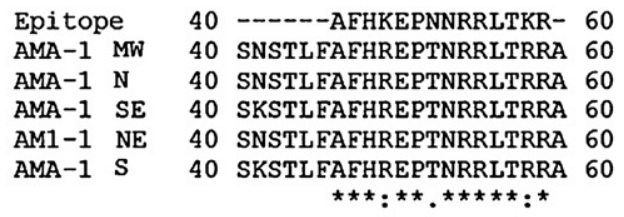

392 ---RGVGMNWATYDKDSG--- 412

392 RISRGVGMNWATYDKDSGMCA 412

392 RISRGVGMNWATYDKDSGMCA 412

392 RISRGVGMNWATYDKDSGMCA 412

392 RISRGVGMNWATYDKDSGMCA 412

392 RISRGVGMNWATYDKDSGMCA 412

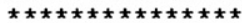

450 ---YVEPRAKNTNKYLDV--- 470

450 TNGYVEPRAKTTNKYLDVPEE 470

450 TNGYVEPRAKTTNKYLDVPEE 470

450 TNGYVEPRAKTTNKYLDVPFE 470

450 TNGYVEPRAKTTNKYLDVPEE 470

450 TNGYVEPRAKTTNKYLDVPEE 470

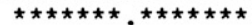

\section{c}

\begin{tabular}{|c|c|c|}
\hline Epitope & 241 & ----------- PGKRTRALLDLRMIE-- ------- \\
\hline TRAP MW & 241 & VWAEWSSCKGECGVPGTRTRALLDLRMIEKPVSGSNGQPG \\
\hline TRAP N & & VWAEWSSCKGECGVPGTRTRALLDLRMIEKPVSGSNGQPG \\
\hline TRAP SE & 241 & VWAEWSSCKGECGVPGTRTRALLDLRMIEKPVSGSNGQPG \\
\hline TRAP NE & 241 & VWAEWSSCKGECGVPGTRTRALLDLRMIEKPVSGSNGQPG \\
\hline TRAP S & 241 & 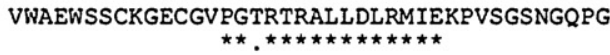 \\
\hline
\end{tabular}

d

Epitope

MSA2C MW

MSA2 C N

MSA2C SE

MSA2C NE

MSA2C S

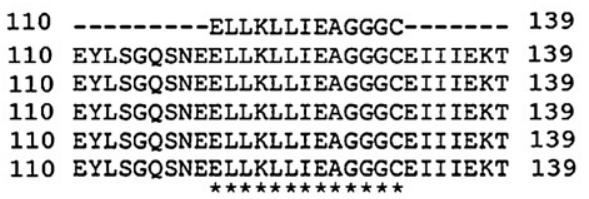

73 -----THDALKAVKQLIKT---- 95

73 TSATKTHDALKAVKQLIKTDAPF 95

73 TSATKTHDALKAVKQLIKTDAPF 95

73 TSATKTHDALKAVKQLIKTDAPF 95

73 TSATKTHDALKAVKQLIKTDAPF 95

73 TSATKTHDALKAVKQLIKTDAPF 95 $* * * * * * * * * * * * * *$

Fig. 1. Alignment of T-cell epitopes of RAP-1 (a), and B-cell epitopes of AMA-1 (b), TRAP (c) and MSA2C (d) with amino acid sequences from respective proteins in Brazilian isolates of Babesia bovis; isolates Northeast (NE), Southeast (SE), South (S), Midwest (MW) and North (N).

in the parasite that contain neutralisation-sensitive B-cell epitopes able to neutralise the invasion of merozoites in erythrocytes (Mosqueda et al., 2002; Wilkowsky et al., 2003).

The genetic conservation of ama-1, acs-1, rap-1, trap, p0 and msa2c among different Brazilian and American strains of $B$. bovis, together with the history of induction components of the Th1 immune response, make these proteins viable candidates to be included in a recombinant cocktail vaccine for cattle babesiosis caused by $B$. bovis.

\section{Conflict of interest statement}

The authors state no conflict of interests.

\section{Acknowledgements}

This study received financial support from the EC project INCO-MEDLABAB 003691 and the Brazilian fostering agencies FUNDECT, FACEPE and CNPq.

\section{Appendix A. Supplementary data}

Supplementary data associated with this article can be found, in the online version, at doi:10.1016/j.vetpar.2012.01.020.

\section{References}

Almeida, M.B., Tortelli, F.P., Riet Correa, B., Ferreira, J.L.M., Soares, M.P., Farias, N.A.R., Riet Correa, F., Schild, A.L., 2006. Tristeza parasitária bovina na região sul do Rio Grande do Sul: estudo retrospectivo de 1978-2005. Pesq. Vet. Bras. 26, 237-242.

Álvarez, J.A., Lopez, U., Rojas, C., Borgonio, V.M., Sanchez, V., Castaneda, R., Vargas, P., Figueroa, J.V., 2010. Immunization of Bos Taurus steers with Babesia bovis recombinant antigens MSA-1, MSA-2c and 12D3. Transbound. Emerg. Dis. 57, 87-90.

Antoniassi, N.A.B., Corrêa, A.M.R., Santos, A.S., Pavarini, S.P., Sonne, L., Bandarra, P.M., Driemeier, D., 2009. Surto de babesiose cerebral em bovinos no Estado do Rio Grande do Sul. Ciência Rural 39, 933-936.

Brayton, K.A., Lau, A.O.T., Herndon, D.R., Hannick, L., Kappmeyer, L.S., Berens, S.J., Bidwell, S.L., Brown, W., Crabtree, J., Fadrosh, D., Feldblum, T., Forberger, H.A., Haas, B.J., Howell, J.M., Khouri, H., Koo, H., Mann, D.J., Norimine, J., Paulsen, I.T., Radune, D., Nene, V.M., 2007. Genome sequence of Babesia bovis and comparative analysis of apicomplexan hemoprotozoa. PLoS Pathogens 3, 1401-1413.

Brown, W.C., Norimine, J., Knowles, D.P., Goff, W.L., 2006. Prospects for recombinant vaccines against Babesia bovis and related parasites. Parasite. Immunol. 28, 315-327.

Callow, L.L., Dalgliesh, R.J., De Vos, A.J., 1997. Development of effective living vaccines against Bovine babesiosis: the longest field trial? Int. J. Parasitol. 27, 747-767.

Câmara, A.C.L., Guimarães, J.A., Dantas, A.C., Mendonça, C.L., Afonso, J.A.B., 2009. Surtos de babesiose cerebral em bovinos leiteiros no nordeste brasileiro. Cien. Anim. Bras. 1, 619-624.

De Vos, A., Bock, R.E., 2000. Vaccination against Bovine babesiosis. Ann. N.Y. Acad. Sci. 916, 540-545.

Dominguez, M., Ehcaide, I., Echaide, S.T., Moqueda, J., Cetrá, B., Suarez, C.E., Florin-Christensen, M., 2010. In silico predicted conserved B-cell 
epitopes in the merozoite surface antigens- 2 family of $B$. bovis are neutralization sensitive. Vet. Parasitol. 167, 216-226.

Fernandes, A.P., Costa, M.M., Coelho, E.A., Michalick, M.S., Freitas, E., Melo, M.N., Luiz Tafuri, W., Resende, D.M., Hermont, V., Abrantes, C.F., Gazzinelli, R.T., 2008. Protective immunity against challenge with Leishmania (Leishmania) chagasi in beagle dogs vaccinated with recombinant A2 protein. Vaccine 26, 5888-5895.

Florin-Christensen, M., Schnittger, L., Dominguez, M., Mesplet, M., Rodriguez, A., Ferreri, L., Asenzo, G., Wilkowsky, S., Farber, M., Echaide, I., Suarez, C., 2007. Search for Babesia bovis vaccine candidates. Parassitologia 1, 9-12.

Gaffar, F.R., Yatsuda, A.P., Franssen, F.F., Vries, E., 2004a. Eritrocyte invasion by Babesia bovis merozoites in inhibited by polyclonal antisera directed against peptides derived from a homologue of Plasmodium falciparum apical membrane antigen 1. Infect. Immun. 72, 2947-2955.

Gaffar, F.R., Yatsuda, A.P., Franssen, F.F., Vries, E.A., 2004b. A Babesia bovis merozoite protein with a domain architecture highly similar to the thrombospondin-related anonymous protein (TRAP) present in Plasmodium sporozoites. Mol. Biochem. Parasitol. 136, 25-34.

Grisi, L., Massard, C.L., Moya-Borja, G.E., Pereira, J.B., 2002. Impacto econômico das principais ectoparasitoses em bovinos no Brasil. Hora Veterinária 125, 8-10.

Hope, M., Riding, G., Menzies, M., Colditz, I., Reverter, A., Willadsen, P., 2005. Potential for recombinant Babesia bovis antigens to protect against a highly virulent isolate. Parasite. Immunol. 27, 439-445.

Kessler, R.H., Sacco, A.M.S., Jesus, E.F., Madruga, C.R., 1987. Desenvolvimento de cepas vivas atenuadas de Babesia bovis e Babesia bigemina: teste preliminar. Pesq. Agro. Bras. 22, 1225-1230.

Kessler, R.H., Schenk, M.A.M., Madruga, C.R., Gomes, A., 1998. Viability of a method for the isolation of Babesia bovis and Babesia bigemina to create a strain bank from five physiographical regions of Brazil. Rev. Bras. Parasitol. Vet. 7, 91-94.

McCosker, P.J., 1981. The global importance of babesiosis. In: Ristic, M., Kreier, J.P. (Eds.), Babesiosis. Academic Press, New York, pp. 1-24.

Mosqueda, J., McElwain, T.F., Palmer, G.H., 2002. Babesia bovis merozoite surface antigen 2 proteins are expressed on the merozoite and sporozoite surface, and specific antibodies inhibit attachment and invasion of erythrocyte. Infect. Immun. 70, 6448-6455.

Musoke, A., Rowlands, S., Nene, V., Nyanjui, J., Katende, J., Spooner, P., Mwaura, S., Odongo, D., Nkonge, C., Mbogo, S., Bishop, R., Morzria, S., 2005. Subunit vaccine based on the p67 major surface protein of Theileria parva sporozoites reduces severity of infection derived from field tick challenge. Vaccine 23, 3084-3095.

Nari, A., Solari, M.A., Cardozo, H., 1979. Hemovacuna para el control de Babesia spp. y Anaplasma marginale en el Uruguay. Veterinária 15, 137-148.

Norimine, J., Ruef, B.J., Palmer, G.H., Knowles, D.P., Herndon, D.R., Rice-Ficht, A.C., Brown, W.C., 2006. A novel 78-kDa fatty acyl-CoA synthetase (ACS1) of Babesia bovis stimulates memory CD4+ T lymphocyte responses in B. bovis-immune cattle. Mol. Biochem. Parasitol. $147,20-29$.

Norimine, J., Suarez, C.E., McElwain, T.F., Florin-Christensen, M., Brown, W.C., 2002. Immunodominant epitopes in Babesia bovis rhoptryassociated protein 1 that elicit memory CD4(+)-T-lymphocyte responses in B. bovis-immune individuals are located in the aminoterminal domain. Infect. Immun. 70, 2039-2048.

Ojeda, J.J., Orozco, L., Flores, R., Figueroa, J.V., Álvarez, J.A., 2010. Validation of an attenuated live vaccine against Babesiosis in native cattle in a endemic area. Transbound. Emerg. Dis. 57, 84-86.

Perez, J., Javier Perez, J., Vargas, P., Antonio Alvarez, J., Rojas, C., Figueroa, J.V., 2010. Sequence conservation of the 12D3 gene in Mexican isolates of Babesia bovis. Transbound. Emerg. Dis. 57, 57-60.

Rajeshwari, K., Patel, K., Nambeesan, S., Mehta, M., Sehgal, A., Chakraborty, T., Sharma, S., 2004. The P domain of the P0 protein of Plasmodium falciparum protects against challenge with malaria parasites. Infect. Immun. 72, 5515-5521.

Ramos, C.A.N., Araújo, F.R., Souza, I.I.F., Oliveira, R.H.M., Elisei, C., Soares, C.O., Sacco, A.M.S., Rosinha, G.M.S., Alves, L.C., 2009. Molecular and antigenic characterisation of ribosomal phosphoprotein P0 from Babesia bovis. Mem. Inst. Oswaldo Cruz. 104, 998-1002.

Ramos, C.A.N., Araújo, F.R., Souza, I.I.F., Bacanelli, G., Luiz, H.L., Russi, L.S., Oliveira, R.H.M., Soares, C.O., Rosinha, G.M.S., Alves, L.C., 2011. Realtime polymerase chain reaction based on $m s a 2 c$ gene for detection of Babesia bovis. Vet. Parasitol. 176, 79-83.

Rodrigues, A., Rech, R.R., Barros, R.R., Fighera, R.A., Barros, C.S.L., 2005. Babesiose cerebral em bovinos: 20 casos. Ciência Rural 35 121-125.

Suarez, C.E., Palmer, G.H., Hötzel, I., Hines, S.A., McElwain, T.F., 1998. Sequence and functional analysis of the intergenic regions separating babesial rhoptry-associated protein-1 (rap-1) genes. Exp. Parasitol. 90, 189-194.

Wilkowsky, S.E., Farber, M., Echaide, I., Torioni de Echaide, S., Zamorano, P.I., Dominguez, M., Suarez, C.E., Florin Christensen, M., 2003. Babesia bovis merozoite surface protein-2c (MSA-2c) contains highly immunogenic, conserved B-cell epitopes that elicit neutralizationsensitive antibodies in cattle. Mol. Biochem. Parasitol. 127, 133-141.

Wright, I.G., Casu, R., Commins, M.A., Dalrymple, B.P., Gale, K.R., Goodger, B.V., Riddles, P.W., Waltisbuhl, D.J., Abetz, I., Berrie, D.A., Bowles, Y., Dimmock, C., Hayes, T., Kalnins, H., Leatch, G., McRae, R., Montague, P.E., Nisbet, I.T., Parrodi, F., Peters, J.M., Scheiwe, P.C., Smith, W., RodeBramanis, K., White, M.A., 1992. The development of a recombinant Babesia vaccine. Vet. Parasitol. 44, 3-13.

Wright, I.G., Goodger, B.V., 1988. Pathogenesis of babesiosis. In: Ristic, M. (Ed.), Babesiosis of Domestic Animals and Man. CRC Press, Boca Raton, FL, pp. 100-118. 